\title{
MERCOSUL: ANTECEDENTES, ORIGEM E DESEMPENHO RECENTE
}

\author{
Ricardo Dathein ${ }^{1}$
}

\section{INTRODUÇÃO}

Os processos de integração econômica já possuem uma longa história na América Latina, apresentando muitos fracassos, mas também sucessos que estimulam, juntamente com os condicionantes internacionais externos à área, a continuidade das iniciativas. Nesse contexto, o Mercosul apresenta-se como uma importante experiência de integração no Cone Sul, que está passando atualmente por dificuldades, mas que possui perspectivas de recuperação.

O objetivo do presente trabalho é fazer uma análise sobre os antecedentes históricos e em relação ao processo que deu origem ao Mercosul. Além disso, busca-se examinar o desempenho e a atualidade, e tirar conclusões sobre o futuro do processo, com a análise de dados econômicos dessa experiência de integração. Para tanto, o artigo inicia fazendo uma discussão sobre os acontecimentos que antecederam e condicionaram as primeiras iniciativas de integração econômica no subcontinente, incluindo as discussões e propostas da Cepal (Comissão Econômica para a América Latina e Caribe). Após, são feitas análises sobre as experiências da Alalc (Associação Latino-Americana de Livre Comércio), da Aladi (Associação LatinoAmericana de Integração) e das iniciativas de acordos bilaterais entre Argentina e Brasil nos anos 1980. O Mercosul, especificamente, é tratado a seguir, em suas constituição e primeiros resultados. O desempenho econômico do bloco e dos países constituintes, até o presente, é tratado brevemente na seqüência. Por fim, são elaboradas conclusões sobre o processo e suas possibilidades perspectivas.

1 Professor Adjunto do Departamento de Ciências Econômicas e do Programa de Pós-Graduação em Economia da UFRGS. E-mail: ricardo.dathein@ufrgs.br 


\section{ANTECEDENTES DA INTEGRAÇÃO ECONÔMICA NA AMÉRICA LATINA}

A Segunda Guerra Mundial trouxe dificuldades para o comércio entre a América Latina (AL) e os países desenvolvidos. Isso levou alguns países da região, especialmente os do Cone Sul, a assinarem acordos comerciais entre si, o que provocou um aumento das transações intra-regionais durante e logo após a guerra. Esses acordos bilaterais, além de provocarem a diversificação do comércio entre os países da $\mathrm{AL}$, fizeram as trocas intrazonais chegarem a $11 \%$ do comércio total em 1954 (VACCHINO, 1987).

Até 1955, os maiores países latino-americanos, em geral, tiveram um grande progresso, diversificando e industrializando suas economias. Segundo a Cepal, entre 1945 e 1955 a AL cresceu rapidamente $(2,7 \%$ ao ano por habitante, em média), entre outros motivos porque o preço internacional dos produtos exportados aumentou (ocorreu um auge nos mercados internacionais de matérias-primas) e porque houve uma bem sucedida política de substituição de importações, além de ter ocorrido uma entrada considerável de capital estrangeiro. ${ }^{1}$ A industrialização, entretanto, ocorreu principalmente na produção de bens de consumo, que requeriam investimentos e mercados menores.

No entanto, na segunda metade dos anos 1950, a Cepal constatou e previu que a combinação favorável de fatores externos não se repetiria nos quinze anos seguintes. As condições internacionais seriam mais semelhantes às posteriores à Crise Mundial da década de 1930. A projeção para o período posterior a 1955 era de uma capacidade de importar estagnada, mesmo com aumento de exportações. De fato, com a recuperação das economias desenvolvidas e os empecilhos impostos pelo Gatt (restrições a acordos bilaterais que geravam preferências), o comércio local voltou a cair. ${ }^{2}$

$\mathrm{Na}$ segunda metade dos anos 1950, segundo a Cepal, chegou-se a um impasse no desenvolvimento da AL. Os países dependiam da importação de máquinas, equipamentos e tecnologia dos países desenvolvidos para passar à etapa seguinte da industrialização. A capacidade para importar,

As exportações latino-americanas cresceram 2,3\% ao ano, em média, entre 1945 e 1955, enquanto o poder de compra das exportações havia aumentado 5,4\% ao ano, o que indicava uma melhora nas relações de troca (VERSIANI, 1987, p. 27).

2 Segundo S. Dell, citado pelo BID (1984, p. 99), o comércio intraregional reduziu-se em 26\% entre 1955 e 1961. Entre os países da futura ALALC, essa queda foi de 41\%. De 1953 a 1960, as exportações entre os países latino-americanos reduziram-se de 12\% a 7,9\% do total das exportações (MARTÍNEZ et al., 1978, p. 10). 
portanto, era decisiva para a continuidade dos investimentos. E justamente nesse momento, quando se necessitava mais, houve uma piora na capacidade de importar.

A Cepal, criada em fevereiro de 1948, trabalhava na adaptação da teoria do desenvolvimento às condições particulares da AL e estudava o comércio intra e extra-regional. Durante muitos anos a Cepal foi subestimada pelos governos dos países desenvolvidos, que consideravam seus estudos "especulações de duvidoso valor acadêmico" (WIONCZEK, 1989, p. 45). O fato é que sua criação foi fundamental para o desenvolvimento das idéias integracionistas na AL. Foi ela, em boa medida, que deu o fundamento teórico e funcionou como agente catalisador do processo integracionista (SILVA, 1990). ${ }^{3}$

Segundo a Cepal, a industrialização era essencial para tirar os países latino-americanos do atraso econômico, mas era necessário também expandir o comércio exterior além dos produtos primários. A idéia era criar uma estrutura diversificada de produção e, por isso, a industrialização fechada nos mercados nacionais não era suficiente, pois essa não permitia um aumento das importações. Para aumentar as exportações industriais, era necessário aumentar a eficiência e a competitividade, sendo isso somente alcançável com um mercado mais amplo que o de cada país isoladamente.

A idéia, então, era aprofundar o processo de substituição de importações, passando da fase de produção de bens de consumo para a de bens intermediários e de capital. Como essas indústrias demandavam mercados maiores, propunha-se o abandono da industrialização voltada prioritariamente para o mercado interno. A solução para a ampliação das escalas de produção seria a "transferência do processo de substituição de importações da escala nacional para a continental" (VERSIANI, 1987, p. 28). A integração econômica era apontada, desse modo, como a alternativa que os países possuíam para escapar à estagnação econômica.

Mesmo para as economias maiores, como Argentina e Brasil, a integração seria importante, pois a produção de bens de capital não poderia

3 Em uma resolução da Cepal, de junho de 1948, já aparecia a possibilidade de ser criada futuramente uma união aduaneira na AL. Em um estudo de 1949, sobre a economia da AL, aparece o conceito de integração da economia latino-americana (SILVA, 1990). No entanto, em meados da década de 1950, ainda se falava mais no conceito de cooperação econômica (incluindo ajuda dos EUA para a AL), e a Cepal centrava seus estudos na relação dos preços de intercâmbio, na ajuda externa e no comércio tradicional na AL. O comércio intra-regional era muito pequeno, sendo mais importante o da Argentina, Brasil, Chile e Uruguai; por isso, os estudos da Cepal sobre comércio centravamse em propostas para essa região e não para toda a AL (WIONCZEK, 1989). 
ser feita em escala ótima apenas para o mercado interno. O isolamento, em síntese, criaria estrangulamentos econômicos, ineficiência, e prejudicaria a competitividade internacional.

Tendo como pano de fundo a piora da posição econômica da AL, o fato de que não havia nenhuma política dos países desenvolvidos para a região, e "impressionados pela assinatura do Tratado de Roma, em março de 1957", criando o Mercado Comum Europeu (que era visto como exemplo e ameaça), os governos aprovaram a conveniência de estabelecer, gradual e progressivamente, de uma maneira multilateral e competitiva, um mercado comum latino-americano (WIONCZEK, 1989, p. 46). Como conseqüência, entre os anos de 1957 e 1959, a Cepal concentrou-se na elaboração de estudos visando à formação do mercado regional.

A CEPAL propunha inicialmente um mercado regional restrito a poucos países (onde as circunstâncias fossem mais propícias) e concentrada em determinados produtos. A ampliação e a adesão seriam progressivas, com uma visão o mais pragmática possível (MENEZES, 1990). A meta seria o "equilíbrio na balança comercial de cada país com o resto da área" (VERSIANI, 1987, p. 28), o que seria alcançado pela aplicação do princípio da reciprocidade. Isso garantiria uma participação igualitária dos países nos benefícios da ampliação do comércio, o que era visto como indispensável para o êxito da integração.

\section{ASSOCIAÇÃO LATINO-AMERICANA DE LIVRE COMÉRCIO (ALALC)}

A Alalc foi criada a partir da assinatura do Tratado de Montevidéu, em fevereiro de 1960. Foi o mais importante grupo de integração da América Latina, por contar com a maior parte da produção e população do subcontinente, até a sua substituição, em 1980, pela Aladi. ${ }^{4}$ O tratado previa que qualquer país poderia participar da associação, sem exceção. No entanto, Cuba solicitou sua adesão em 1962, a qual não foi aceita sob alegação de

4 Os países que assinaram o tratado foram Argentina, Brasil, Chile, México, Paraguai, Peru e Uruguai. A Colômbia aderiu em setembro de 1961 e o Equador em novembro do mesmo ano. Ficaram fora do tratado, neste momento, por exemplo, Bolívia, Cuba, Venezuela e América Central. Essa região estava criando o MCCA(Mercado Comum Centro-Americano), mas desejava-se que, mais tarde, ocorresse uma fusão para se chegar a um mercado comum mais amplo. 
incompatibilidade entre os sistemas econômicos. ${ }^{5}$ Venezuela e Bolívia, que exportavam petróleo e minerais para o Primeiro Mundo, e lá compravam os produtos que desejavam, relutaram em aderir, pois achavam que isso não lhes traria benefícios, e que acabariam subsidiando as indústrias argentina, brasileira e mexicana (MENEZES, 1990). Mesmo assim, a Venezuela aderiu em 1966 e a Bolívia em 1967.

No Tratado de Montevidéu, constava como objetivo da ALALC acelerar o desenvolvimento econômico da região, e que, para isso, dever-seiam ampliar as dimensões dos mercados e coordenar os planos de desenvolvimento dos países. O objetivo de uma progressiva complementação e integração, para se chegar a um mercado comum latino-americano, alcançarse-ia de forma gradual. Estabelecia-se que a zona de livre comércio seria alcançada em um prazo não superior a doze anos, durante os quais a liberação ocorreria passo a passo, com negociações periódicas. Como o tratado entrou em vigor em junho de 1961, o prazo de doze anos venceria em 1973. A idéia de fazer os acordos progressivamente era de permitir a adaptação das economias às novas condições, e também promover a sucessiva complementação das economias dos países da zona (WIONCZEK, 1989).

A partir de 1959, os Estados Unidos passaram a exercer uma maior influência no processo de integração latino-americano. Em março de 1961, o Presidente Kennedy convidou todos os países americanos para participarem da "Aliança para o Progresso", que foi aprovada por vinte delegações em agosto de 1961, em Punta del Este. Na declaração aprovada, dispunha-se que um dos objetivos seria acelerar a integração. A "Aliança para o Progresso" acabou sucumbindo pelas suas motivações político-ideológicas, mas facilitou a interferência dos EUA no processo de integração da AL, o que foi feito principalmente através da AID (Agency for International Development) e do BID (SILVA, 1990).

Em 1967, ocorreu uma reunião em Punta del Este, com todos os presidentes americanos, inclusive o dos EUA. Um artigo da Declaração dos Presidentes da América, resultante da reunião, admitiu a liberdade para a criação de agrupamentos sub-regionais no interior da ALALC. Isto abriu caminho para a criação do Grupo Andino, pois os países dessa região dese-

Os motivos mais fortes, não explicitados, foram de ordem política. Um ano antes, havia ocorrido a tentativa de invasão na Baía dos Porcos, em Cuba, e a administração Kennedy, ao contrário da posição dos EUA nos oito anos anteriores, estava se colocando favorável à integração, e acenava com ajuda econômica. Além disso, o momento, em muitos países, era de "luta contra o comunismo" (MENEZES, 1990). O México foi o único país que se opôs à posição que predominou (MARTÍNEZ et al., 1978). Cuba, então, não foi admitida na ALALC, além de ter sido excluída da OEA. 
javam implementar um esquema de integração mais ambicioso, o que não estavam conseguindo no âmbito de toda a ALALC. A declaração afirmou também o propósito de iniciar em 1970 a implementação de um mercado comum, com um prazo de quinze anos, mas esta decisão não foi encaminhada.

Como a liberação comercial estancou, a ALALC passou a centrar maior atenção nos acordos de complementação industrial. No Quarto Período de Sessões da Conferência das Partes Contratantes, em dezembro de 1964, decidiu-se a revogação da cláusula de nação mais favorecida para os acordos de complementação. Como estes passaram a ser o principal mecanismo da integração, isto foi, na prática, um recuo ao bilateralismo (VERSIANI, 1987). De 1966 a 1978 foram assinados 23 destes acordos, abarcando 1.447 produtos. Esses acordos podiam ser aplicados para a indústria já existente ou para os novos investimentos, mas neste segundo caso praticamente não foram usados. Uma crítica que logo surgiu foi que somente as multinacionais beneficiar-se-iam desses acordos, pois essas já possuíam subsidiárias em vários países, e passariam a produzir os componentes e fazer a montagem dos seus produtos nos países que apresentavam os menores custos. Efetivamente, os acordos concentraram-se nos maiores países e em setores controlados por poucas empresas, principalmente multinacionais. Isso fez, algumas vezes, a especialização intra-industrial transformar-se em uma especialização intrafirma. O primeiro acordo, por exemplo, envolveu uma única firma, a IBM (VERSIANI, 1987; BID, 1984; MENEZES, 1990). O comércio que se originou dos acordos de complementação, que representava $1 \%$ das importações intra-regionais em 1966, passou a 7\% em 1971, mas caiu para 4\% em 1980, indicando as crescentes dificuldades de avanço também deste mecanismo.

Em dezembro de 1969, como resultado da Conferência Anual das Partes Contratantes, foi assinado o Protocolo de Caracas, que alterou o tratado original. A exigência de redução anual de $8 \%$ da média ponderada das tarifas vigentes para terceiros países nas Listas Nacionais foi rebaixada para $2,9 \%$ ao ano. O ritmo das negociações para as liberações comerciais foi reduzido, e o prazo final para se chegar à zona de livre comércio foi postergado de 1973 para 31 de dezembro de 1980, enquanto a aplicação da Lista Comum foi suspensa até dezembro de 1974, que foi o prazo fixado para se chegar a novas normas para essa Lista. No entanto, a ALALC enfrentou um grande imobilismo, principalmente depois de 1969, e as metas não foram cumpridas. 
Mesmo com todas as dificuldades, o comércio entre os países da Alalc aumentou. ${ }^{6}$ A composição das exportações da AL, de outra parte, alterou-se muito entre 1965 e 1979. Houve uma diminuição sensível dos alimentos básicos e matérias-primas, e um aumento da participação dos produtos manufaturados nas exportações. Esse comportamento foi muito mais acentuado para as exportações intra-regionais do que para as extra-regionais.

Mesmo que as negociações tenham estagnado, depois de 1964 o intercâmbio recíproco continuou crescendo. Isto ocorreu porque, até 1965, quase dois terços das preferências alfandegárias já outorgadas ainda não eram aplicadas, tendo sua utilização crescido à medida que se ampliavam os canais de comercialização, cresciam as informações sobre oportunidades, ajustava-se a produção, etc. Outro motivo foi que os acordos financeiros, que entraram em operação posteriormente, estimularam a utilização das preferências. Mesmo o intercâmbio de produtos que não tinham preferências "diretas" foi beneficiado pelo aumento das informações e dos canais de comercialização e financeiros.

Para Versiani (1987), no entanto, o crescimento das exportações totais deve ser visto como resultado das altas taxas de crescimento do produto dos países industrializados, pelo menos até 1973. O aumento das exportações intra-regionais teria sido o resultado das altas taxas de crescimento das economias latino-americanas situadas neste contexto global, não se podendo creditar estes avanços apenas aos acordos da Alalc. Pelo contrário, a proporção de produtos negociados segundo o tratado no comércio intra-regional aumentou até 1966 , mas depois declinou continuamente. ${ }^{7}$ Além disso, o aumento das exportações de manufaturados pode ser creditado

6 Em 1960, a soma das exportações e importações intra-Alalc (considerando todos os países que vieram a constituir a Associação) foi de US\$ 1,2 bilhão. Em 1970, esse total chegou a US\$ 2,6 bilhões e, em 1980, a US\$ 21,4 bilhões. As taxas de crescimento médias anuais correspondentes foram de $8,0 \%$ de 1960 a 1970, e de $23,3 \%$ de 1970 a 1980. De 1960 a 1980, a média anual foi de 15,4\%, o que foi excepcional, e contrariou as previsões feitas pela Cepal na década de 1950. Por outro lado, a relação entre as exportações intra-regionais e as exportações totais, para a AL como um todo, subiu de 12,6\% em 1965 para 13,8\% em 1970 e 17,0\% em 1975, ficando em 16,7\% em 1979. Tomando-se somente os países da Alalc, a relação entre o intercâmbio comercial (exportações mais importações) intra-Alalc e o total, que já havia sido de $11,3 \%$ em 1955, baixou a 8,7\% em 1960 e, posteriormente, elevou-se a 10,7\% em 1970 e 13,0\% em 1980.

7 Entre 1964 e 1966, a participação das mercadorias negociadas no âmbito da ALALC no total das importações intra-regionais foi de $88,7 \%$, tendo este valor caído para 40\% no final da década de 1970 (BLEJER, 1984, p. 19). Em relação ao total das importações do resto do mundo, esse percentual não passou de $6 \%$ em 1979. O comércio 
mais às políticas nacionais de apoio às exportações do que ao estímulo das reduções tarifárias.

O insucesso da Alalc foi determinado por vários fatores. Um deles foi que o processo de substituição de importações continuou forte nos grandes países, ao contrário do que previa a Cepal em suas teses. Como a unidade só ocorreria pela necessidade das economias nacionais, o fato de a integração não fazer parte da estratégia de desenvolvimento dos países levou a que ela não prosperasse. A Alalc não só não teve apoio e suporte nos planos dos governos, quanto também na iniciativa privada e na opinião pública (MENEZES, 1990). ${ }^{8}$

Outro fator fundamental gerador de estancamento da Aalalc foi a impossibilidade de superar as divergências entre os países que desejavam acelerar o processo, e que formaram o Grupo Andino, e os que queriam permanecer dentro dos limites existentes (GERARDI, 1986). Esses últimos, inclusive, interpretavam que o multilateralismo rígido teria sido a principal causa da estagnação das negociações na Alalc. Criticavam, também, a fixação de metas e prazos, o que gerava um efeito psicológico negativo, face aos descumprimentos.

Por outro lado, um problema crucial foi determinado pela desigualdade econômica entre os países. Poderia ocorrer uma reprodução, no nível latino-americano, do padrão de comércio que era criticado, em que os países mais avançados ficavam com os benefícios da industrialização, enquanto os outros produziam e exportavam produtos primários. Isso foi rejeitado pelos países menores, sendo, segundo Blejer (1984), o principal motivo do fracasso da Alalc. ${ }^{9}$ Ocorre que os países tiveram objetivos diferentes na Alalc: os grandes estavam satisfeitos com a expansão de suas exportações, enquanto os pequenos queriam a adoção de medidas não comerciais que servissem para desenvolver sua indústria (VACCHINO, 1987).

Além disso, alguns países promoveram reduções tarifárias significativas para terceiros países, o que reduziu a margem de preferência das importações da região. Os casos mais significativos foram a Argentina, em

intrazonal continuou aumentando via acordos bilaterais entre os países membros da Alalc, e não via tratado (VACCHINO, 1987).

8 Mudanças abruptas e freqüentes na área política sempre acabam por perturbar os processos de cooperação econômica. Foi isto que aconteceu na Alalc durante a década de 1960, quando ocorreram golpes militares na Argentina e no Brasil. Muitos outros problemas políticos graves nas décadas de 1960 e 1970 também dificultaram a integração.

9 Efetivamente, o aumento das exportações intrazonais ocorreu de forma desigual: a participação da Argentina, Brasil e México aumentou de 46\% das exportações 
1967, e o Chile, de 1975 em diante. Em alguns casos, as tarifas a terceiros países chegaram a ser menores que a taxa acordada com os países da Alalc (FFRENCH-DAVIS, 1989).

Durante a década de 1960, os principais países da AL passaram a participar mais ativamente da economia internacional. Nessa década, a produção na AL cresceu 6\% ao ano, em média, e nos primeiros cinco anos da década de 1970 o crescimento chegou quase a 7\% anuais. A economia internacional experimentou altas taxas de crescimento na década de 1960, provocando uma grande expansão da demanda externa para a AL. Além disso, na década de 1970, o financiamento externo foi muito fácil, determinando maiores taxas de crescimento econômico em muitos países. Dessa forma, muitos consideraram que o estrangulamento externo havia sido superado e, portanto, não havia necessidade de assumir maiores compromissos com a integração latino-americana. Os países preferiram conservar seu poder de decisão, privilegiando suas relações com os países europeus e os EUA (VACCHINO, 1987). Por outro lado, o processo de integração não cumpriu a função anticíclica que se esperava, pois o funcionamento do sistema econômico internacional continuou determinando o nível de atividade e as decisões sobre as estratégias e políticas nacionais de desenvolvimento.

Dessa forma, a Alalc não chegou a constituir-se em uma zona de livre comércio. Foi apenas uma zona de preferências comerciais de caráter limitado, para determinados produtos. Em novembro de 1978, foi criado um cronograma de trabalho com o objetivo de reestruturar a Alalc. Em 1979 e 1980 foram feitos estudos e propostas que, por fim, levaram a Alalc a ser substituída pela Aladi (Associação Latino-Americana de Integração).

\section{ASSOCIAÇÃO LATINO-AMERICANA DE INTEGRAÇÃO (ALADI)}

Tendo em vista a falência da Alalc e a iminência do final do período de transição fixado em 1969 pelo Protocolo de Caracas, que ocorreria em 31 de dezembro de 1980, os países membros resolveram realizar estudos para a reestruturação da Alalc. Esses estudos acabaram levando à proposta de um novo tratado. ${ }^{10}$

intrazonais totais, em 1961, para 66\%, em 1973 (MARTÍNEZ et al., 1978, p. 21).

10 Houve uma série de reuniões negociadoras, que fizeram recomendações sobre o "patrimônio histórico" da ALALC, constituído por milhares de concessões tarifárias. Outras recomendações foram a elaboração de novas formas de cooperação 
O tratado que criou a Associação Latino-Americana de Integração foi assinado em 12 de agosto de 1980, entre Argentina, Bolívia, Brasil, Chile, Colômbia, Equador, México, Paraguai, Peru, Uruguai e Venezuela, que eram os mesmos membros da Alalc. O acordo foi chamado "Tratado de Montevidéu 1980" para se diferenciar do de 1960, tendo sido concebido como um tratado-marco, a partir do qual se avançaria de acordo com as vantagens que os países vislumbrassem, e não pelos compromissos assumidos previamente. ${ }^{11}$

O objetivo de longo prazo da Aladi cuja sede ficou em Montevidéu, seria o estabelecimento, gradual e progressivamente, de um mercado comum latino-americano. $\mathrm{O}$ tratado explicitava que a Aladi substituiria a Alalc, inclusive em seus aspectos jurídicos. Explicitava também que estaria aberto à adesão de outros países latino-americanos.

Os principais mecanismos para alcançar os objetivos da Aladi seriam a Preferência Tarifária Regional, ${ }^{12}$ os Acordos de Alcance Regional, ${ }^{13}$ os Acordos de Alcance Parcial ${ }^{14}$ e o Sistema de Apoio aos Países de Menor

com os países de menor desenvolvimento e normas para a realização de acordos com países ou áreas de integração exteriores à Alalc, o que possibilitaria a extensão geográfica do processo. Houve, também, discussões sobre a nova estrutura institucional que deveria ter a associação. Ficou patente, por outro lado, que os membros do Grupo Andino estavam mais dispostos a adotar compromissos para facilitar o aprofundamento do processo.

11 A paulatina redemocratização em vários países do continente, que possibilitou a superação de conflitos e desconfianças mútuas, beneficiou a integração na metade final dos anos 1980. Em conseqüência, nesse período reiniciaram-se os esforços de integração com mais efetividade no Grupo Andino e via os acordos entre Brasil e Argentina.

12 A Preferência Tarifária Regional (PTR) é um mecanismo de negociação multilateral, compreendendo a redução de impostos de importação concedida reciprocamente pelos países membros. A negociação é global, e não produto por produto, como na Alalc. A PTR teve como meta abarcar todo o universo tarifário da região, mas através de um aumento paulatino. Autorizar-se-iam listas de exceções para os casos de prejuízos graves causados pelas liberações comerciais. Este mecanismo não teve a contrariedade do Gatt, pois esse passou a admitir regimes tarifários preferenciais entre países em desenvolvimento.

13 Os Acordos de Alcance Regional são aqueles nos quais participam todos os membros da Aladi, podendo ser comerciais, de complementação econômica, agropecuários, ou outros.

14 Os Acordos de Alcance Parcial, entendidos como uma forma de flexibilizar a integração, são aqueles nos quais não participam todos os países da Aladi, mas somente os que os subscreverem ou aderirem. Esses acordos também podem ser comerciais, de complementação econômica, agropecuários, etc. As normas desses acordos exigem que eles estejam abertos à adesão de outros países da Aladi e que haja cláusulas que propiciem 
Desenvolvimento Econômico Relativo. ${ }^{15}$ O Tratado de Montevidéu 1980 previu também a possibilidade de realização de Acordos de Alcance Parcial com outros países ou áreas de integração da América Latina, e também com países ou áreas de integração de fora da América Latina, desde que fossem atendidas determinadas condições (extensão de concessões, etc.).

A década de 1980 foi de profunda crise econômica na América Latina. A crise internacional, com aumento do preço do petróleo e das taxas de juros, a drástica redução dos fluxos de financiamentos externos e um comércio mundial desfavorável, com queda dos preços de muitos dos produtos de exportação, causaram graves prejuízos ao subcontinente. O serviço da dívida externa conduziu à necessidade de geração de grandes saldos comerciais, levando os países a adotarem programas econômicos que aumentavam exportações e cortavam importações, em detrimento do mercado interno. Essa situação causou prejuízos à nova tentativa de integração regional desde o seu início. Somente na segunda metade da década houve alguma revitalização do processo.

Um fato novo aconteceu em junho de 1990, quando o presidente Bush (pai) lançou a Iniciativa para as Américas, visando à criação de uma zona de livre comércio do Alasca à Terra do Fogo. A proposta foi bem recebida, em geral, pelos governos latino-americanos. Os EUA são o principal parceiro comercial da América Latina, e por isso a proposta gerou grande interesse. No entanto, foi apenas uma proposta esquemática, sem decisões concretas, gerada também pelos conflitos de interesse dos EUA com a CEE e o Japão. ${ }^{16}$

a convergência para uma progressiva multilateralização dos acordos. Significam, no entanto, em termos concretos, o abandono da cláusula de nação mais favorecida existente na Alalc, que garantia a extensão automática aos outros países de acordos parciais.

15 Os países seriam divididos em três categorias: os países de menor desenvolvimento econômico relativo (PMDR) (Bolívia, Equador e Paraguai); os países de desenvolvimento intermediário (Chile, Colômbia, Peru, Uruguai e Venezuela); e os outros membros (Argentina, Brasil e México). Bolívia e Paraguai, enquanto países mediterrâneos, formaram uma categoria especial. O Uruguai, por outro lado, tem um tratamento excepcional, mais favorável que os demais países de desenvolvimento intermediário, mas menor que o tratamento aos PMDR.

16 A Iniciativa para as Américas possuía três pontos: o comercial, com o objetivo de chegar a um acordo de livre comércio; o dos investimentos, com uma pequena proposta de investimentos dos EUA na região; e o da dívida externa, com um oferecimento de redução parcial da dívida da América Latina para com o governo dos EUA, que era de apenas US\$ 12 bilhões, contra uma dívida externa total de mais de US\$ 400 bilhões. Além disso, os EUA faziam exigências e impunham condições. Os acordos, por outro lado, seriam feitos bilateralmente, e não com a Aladi. 
O México, por outro lado, negociou seu ingresso no tratado de livre comércio existente entre Estados Unidos e Canadá, formando-se o NAFTA nos anos 1990. As ligações econômicas do México com esses países são muito mais importantes que as existentes com os membros da Aladi, pois mais de $70 \%$ do seu comércio exterior era realizado com os dois países ao seu norte, principalmente os Estados Unidos.

Durante a década de 1980, e principalmente no seu final, houve uma crescente abertura econômica de vários países da região em relação ao resto do mundo. Isso aumentou o grau de coincidência de interesses, beneficiando um determinado conceito chamado de integração competitiva. No entanto, gerou também questionamentos sobre uma eventual contradição entre o enfoque de abertura externa privilegiando as relações comerciais com os países centrais e a integração via Aladi. Por outro lado, um certo "medo da marginalização" levou também a um apoio à integração regional.

A Aladi passou a uma tendência de realização de acordos subregionais: acordos Brasil-Argentina, Mercosul, revitalização do Grupo Andino, negociações México-EUA-Canadá. Existiu também, segundo Ordóñez (1990), uma "síndrome das datas" gerada pela Europa 92; assim, propôs-se a liberação comercial no Mercosul em 1995 e no Grupo Andino também nesse ano.

A necessidade de moedas fortes para o pagamento dos serviços da dívida externa levou os países a tentarem colocar suas exportações nos países industrializados, em detrimento das exportações locais. Essas também caíram porque, para obter superávit comercial, os países cortaram suas importações sub-regionais, gerando reações semelhantes nos parceiros comerciais, o que amplificou a crise. ${ }^{17}$ Claramente a expansão econômica beneficiou mais as exportações no interior da Aladi, enquanto a recessão trouxe as piores conseqüências, em termos de exportações, para o interior da associação. ${ }^{18} \mathrm{O}$ corte das importações chegou a ser maior que o sofrido pelas

$17 \quad$ Na média anual de 1979 a 1981, os países da Aladi exportaram um total de US\$ 75,3 bilhões, tendo as exportações intra-regionais ficado em US\$10,5 bilhões, ou 13,9\% do total. Na média de 1984 a 1986, por outro lado, as exportações totais cresceram a US\$ 82,7 bilhões, enquanto as intra-regionais reduziram-se a US\$ 7,6 bilhões; com isso, a participação desta última no total ficou em 9,1\%. Ffrench-Davis (1989) observa que parte das menores exportações intra-Aladi encontrou mercado extra-regional.

18 A taxa de crescimento média anual das exportações intra-Aladi foi de $24,0 \%$ de 1970 a 1980 , enquanto houve uma queda média anual de 6,3\% de 1980 a 1985. Já as exportações totais dos membros da Aladi cresceram 20,2\% de 1970 a 1980 e continuaram crescendo $0,9 \%$ de 1980 a 1985 (médias anuais). 
importações intra-regionais. ${ }^{19}$ A partir de 1986, tanto as exportações quanto as importações, intra e extra-regionais, voltaram a crescer. Em 1990, as exportações e as importações intra-Aladi chegaram mais ou menos aos mesmos níveis do início da década de 1980.

Em 1984, das importações intra-regionais efetuadas com preferências tarifárias, $84 \%$ foram resultantes de acordos bilaterais. Isto demonstra a tendência ao bilateralismo resultante da crise dos acordos multilaterais (ALADI e Grupo Andino). Além disso, em 1981 somente 25\% das importações intra-regionais corresponderam a produtos negociados via Aladi. Houve um lento aumento desse percentual, mas mesmo assim esse chegou a apenas $41 \%$ em 1987. A maioria das importações intra-Aladi, portanto, ainda eram feitas sem o uso dos instrumentos da Aladi.

De outra parte, existe uma grande concentração no comércio intraAladi. Em 1984, por exemplo, o Brasil participava com 35,2\% das exportações e a Argentina com 16,4\%, resultando em 51,6\% das exportações intrazonais somente em dois dos onze países, o que torna o resultado global muito dependente do comportamento econômico destes dois países. Por essa importância no comércio intra-regional, Argentina, Brasil e México foram os principais responsáveis pela queda do comércio, pois realizaram cortes profundos nas suas importações da região na primeira metade da década de 1980.

AAladi é o acordo de integração mais limitado da América Latina, possuindo um enfoque basicamente comercialista. Para Magariños (1990), o Tratado de Montevidéu 1980 estimulou o bilateralismo, enquanto os instrumentos multilaterais tinham uma formulação genérica e não eram obrigatórios. O tratado não incorporou muitos aspectos importantes que poderiam gerar uma maior integração, como, por exemplo, a cooperação industrial, a harmonização de políticas econômicas ou a integração funcional, em áreas específicas como educação, saúde, etc. Nada colocou também sobre uma tarifa externa comum ou sobre prazos ou metas específicas. Não ficou claro, também, como seria feita a proposta multilateralização progressiva das experiências de integração parciais. Houve, na realidade, uma prevalência absoluta do princípio da flexibilidade sobre o da convergência. ${ }^{20}$

19 O valor das importações totais da Aladi, por outro lado, reduziu-se de US\$ 84,5 bilhões em 1980 a US\$ 48,4 bilhões em 1983, voltando a crescer para US\$ 60,7 bilhões em 1987.

20 A explicação dada para a pequena amplitude dos objetivos e instrumentos da Aladi foi a de que se partia da percepção realista das falhas da Alalc, e também de que a Aladi era o resultado das condições vigentes na época, que colocavam a integração como mecanismo de baixa prioridade nas políticas nacionais internas e externas. Dessa forma, os compromissos compulsórios e automáticos da Alalc foram abandonados, numa 
No entanto, para Magariños (1990), por exemplo, o conceito de que a Alalc não funcionou porque era excessivamente ambiciosa e rígida era falso, pois, na realidade, a fórmula da Alalc já era extremamente modesta, fixando como meta apenas uma zona de livre comércio, o que não passa de uma fase inicial de um processo de integração. Magariños (1991, p. 3) acrescenta também que "a Aladi, apesar de denominar-se como uma Associação de Integração tem, por seu bilateralismo exacerbado, um forte viés antiintegracionista". A decisão, por outro lado, de não se fixar prazos ou metas para não se incorrer em descumprimentos teria provocado, como resultado, um vazio ao processo.

A integração foi afetada também pela crise econômica dos anos 1980. Como resultado dessa crise, o PIB per capita reduziu-se em nove dos onze países, de 1981 a 1990. Somente a Colômbia e o Chile tiveram pequenos aumentos. A dívida externa crescente levou ao estrangulamento externo e à adoção de políticas econômicas restritivas. O problema da dívida externa poderia ter sido um fator gerador de ações conjuntas no marco da Aladi, inclusive pelos prejuízos causados aos mecanismos financeiros coletivos. No entanto, ao invés disso, foram realizados apenas pequenos esforços conjuntos, via o chamado Consenso de Cartagena e, mesmo assim, sem maiores avanços. Mais tarde, o Grupo do Rio também coordenou ações de política externa, mas novamente sem conseqüências positivas.

Segundo Gonçalves et al. (1998, p. 86), "uma explicação para o fracasso [das tentativas de integração] é o fato de que os governos latinoamericanos viam seus mercados domésticos como um ativo estratégico, e seus vizinhos latino-americanos como concorrentes no fornecimento de produtos primários ou processados para um mercado internacional cuja demanda tinha baixíssima elasticidade-renda”. Por isso, os países portam-se mais como concorrentes do que como parceiros, comportamento que dificulta o avanço das experiências e que, em casos de crises econômicas, provoca sempre o retrocesso dos processos de integração.

Dessa forma, segundo a secretaria da Alaldi, o não avanço da integração foi resultado da adoção de atitudes defensivas para resguardar a atividade econômica interna e para cumprir os compromissos econômicos externos, além de que houve redução da vontade política de avançar na integração e também falta de respostas dos mecanismos existentes aos per-

tentativa de adequação do esquema à realidade. A flexibilidade e o pragmatismo foram eleitos elementos essenciais no novo processo. O instrumento dos acordos parciais, entre dois ou mais países, partia da experiência que já vinha ocorrendo, por exemplo, com o Grupo Andino e nos acordos do Uruguai com o Brasil e a Argentina. 
sistentes desequilíbrios comerciais entre os países membros (VACCHINO, 1987). ${ }^{21}$

Quanto aos mecanismos de apoio aos países de menor desenvolvimento econômico relativo e aos de desenvolvimento intermediário, esses tiveram uma formulação muito genérica, e a ausência de regulamentação debilitou sua aplicação e, portanto, seus resultados. Houve uma ênfase nos aspectos comerciais, o que, pelas limitações estruturais dos PMDR, levou ao pequeno aproveitamento das concessões, pois não existia produção exportável para a maioria dos itens incluídos nas listas de liberação. Desse modo, os resultados não foram satisfatórios.

Sempre houve uma difícil relação entre os "governistas" e os "supranacionalistas" na Aladi (MAGARIÑOS, 1990). Segundo Magariños (1991, p. 4) "a Aladi não tem vida exterior própria, não é ator na diplomacia internacional, nem mesmo no campo específico do comércio". Desse modo, não existiu um órgão comunitário que defendesse ou expressasse o interesse regional, atuando como contrapeso ao nacionalismo e aos interesses particulares dos países membros. Nas negociações sobre dívida externa, financiamento e comércio internacional, por exemplo, os governos preferiram relacionar-se individual e diretamente com os países industrializados, ficando a política conjunta no campo da retórica.

Mesmo com todos os problemas, até o final de 1989 haviam sido assinados cinco Acordos de Alcance Regional e aproximadamente noventa Acordos de Alcance Parcial. Além disso, a Aladi possui um Regime Geral de Origem, um Regime Regional de Salvaguardas e uma nomenclatura aduaneira comum, além de uma Câmara de Compensação. Isto faz da Aladi uma zona de preferências tarifárias de caráter parcial.

O Tratado constitutivo da Aladi admitiu, de forma pragmática, a formação de acordos bilaterais ou multilaterais sub-regionais, mas sempre com o objetivo de sua posterior ampliação para o conjunto dos membros da Aladi. A própria negociação do "patrimônio histórico" da Alalc gerou muitos convênios bilaterais. Nas negociações do final dos anos 1980, em realidade, a enfraquecida Aladi não cumpria papel relevante. No entanto, a multilateralização parcial dos acordos bilaterais entre Brasil e Argentina, com

${ }^{21}$ Outro problema para o processo de integração é que as decisões necessitam ser aprovadas internamente por cada país membro para terem validade nesses países, o que provoca demoras de meses, ou até de anos em alguns casos, prejudicando a eficácia das medidas e dificultando as relações recíprocas entre os membros. 
a formação do Mercosul, não deixa de ser o cumprimento, mesmo que não total, da proposta da Aladi de ampliação da abrangência dos acordos. ${ }^{22}$

A Aladi resultou por ficar dividida em dois subgrupos principais: Grupo Andino e Mercosul. O México ficou, com isso, isolado ao sul, e aproximou-se com os seus dois vizinhos do norte, com os quais tem maiores interesses econômicos. O Chile, por outro lado, dada sua política particular, não tem interesse em acordos comerciais multilaterais com seus vizinhos, preferindo fazer acordos bilaterais de liberação comercial. A Aladi, nessa configuração, ficou praticamente sem papel no avanço do processo de integração regional.

\section{PROCESSO DE INTEGRAÇÃo ENTRE ARGENTINA E BRASIL}

A segunda metade dos anos 1980 foi marcada pela retomada do processo de integração nos dois países economicamente mais importantes da América do Sul, depois do grande retrocesso do início da década. Esse processo foi aprofundando-se sucessivamente até a sua ampliação para o Paraguai e o Uruguai, através do Mercosul..$^{23}$

A primeira metade dos anos 1980 foi caracterizada, tanto na Argentina quanto no Brasil, por elevação das taxas de inflação, crise econômica, aumento dos saldos da balança comercial e aumento da dívida externa. Ao mesmo tempo, houve uma grande redução das importações totais e também das procedentes da América Latina. A "crise do endividamento introdu-

22 Uma das características generalizadas na América Latina, presentemente, é a adoção de políticas de abertura comercial. Essas, apesar do discurso que as consideram compatíveis com o processo de integração ("integração competitiva"), podem significar, na prática, forças contrárias ao incremento do comércio intrazonal. Todavia, por outro lado, passou a ocorrer uma crescente dinamização de processos de cooperação entre pares ou grupos de países, através de acordos de liberação comercial. Ao mesmo tempo, não existe interesse, na maioria dos casos, em ampliar a integração para outros campos, além do comercial.

23 Um fator importante que estimulou a busca de acordos foi a redução do comércio recíproco, que foi muito grande nos primeiros anos da década de 1980 . O comércio total (exportações mais importações) entre Argentina e Brasil sofreu uma forte queda nos primeiros anos da década de 1980, depois de ter-se elevado muito de 1975 a 1980. De 1985 em diante o comércio voltou a crescer. Além disso, os saldos comerciais foram persistentemente favoráveis ao Brasil, prejudicando a Argentina. As exportações brasileiras para o país vizinho, por outro lado, eram predominantemente de manufaturados, enquanto as importações eram majoritariamente de produtos primários, tendendo a consolidar um padrão de comércio também desfavorável à Argentina. 
ziu um viés antiintegração na América Latina”, segundo Munhoz (1987, p. 89). Foi também em reação a essa situação que os dois países aproximaram-se. A percepção da crescente posição marginal e vulnerável dos países latinoamericanos no contexto internacional, por outro lado, também levou ao aumento do interesse pela integração na Argentina e Brasil.

A partir de 1985, com a posse de Sarney no Brasil, e dada a anterior volta à democracia na Argentina, fortaleceu-se a sintonia política entre os dois países. O restabelecimento da democracia foi um fator decisivo no impulso à integração e cooperação. Desse modo, chegou-se a uma política de aproximação formalmente anunciada em novembro de 1985, quando os presidentes da Argentina e Brasil encontraram-se em Foz do Iguaçu. Através da Declaração de Iguaçu foi expressa a vontade política de superar a tradicional rivalidade que caracterizou as relações entre ambos os países, refletindo as novas condições democráticas da região e a necessidade de cooperação para ampliar o desenvolvimento econômico.

Em julho de 1986, os presidentes Sarney e Alfonsín encontraram-se em Buenos Aires para a aprovação do Programa de Integração e Cooperação Econômica (PICE).$^{24}$ No encontro, foram assinados a Ata para a Integração Brasileiro-Argentina e doze protocolos, tratando de temas específicos. ${ }^{25}$ A proposta mais importante foi a da integração intra-setorial, através da qual se buscaria um "equilíbrio progressivo, qualitativo e quantitativo, do inter-

24 Os princípios do PICE seriam o gradualismo, com fases anuais de definição, negociação, execução e avaliação; a flexibilidade, permitindo o ajuste de alcance, ritmo e objetivos; e o equilíbrio, impedindo a especialização das economias em setores específicos, e estimulando a integração intra-setorial. Buscava-se, também, a harmonização progressiva de políticas e a participação ativa dos empresários, e decidiuse elaborar o programa por fases, com conjuntos reduzidos de projetos.

${ }_{25}$ Os protocolos trataram dos seguintes temas: produção, comércio e desenvolvimento tecnológico de bens de capital; produção, armazenagem, transporte e abastecimento de trigo; abastecimento alimentar; expansão do comércio; empresas binacionais; assuntos financeiros; criação de um fundo de investimentos; cooperação na área energética; projetos sobre biotecnologia; criação do Centro Brasil-Argentina de Altos Estudos Econômicos; informação imediata e assistência recíproca em caso de acidentes nucleares e emergências radiológicas; e cooperação técnica, industrial e comercial na área aeronáutica. Ainda em 1986, foram acrescentados mais cinco protocolos: cooperação e integração no setor siderúrgico; transporte terrestre; transporte marítimo; comunicações; e cooperação nuclear. Posteriormente, em 1987, mais três protocolos foram assinados: sobre cultura; administração pública; e criação de uma moeda escritural comum, o "gaúcho". Em 1988, somaram-se mais três: integração e cooperação na indústria automobilística e na indústria alimentícia e sobre regiões fronteiriças. Em 1989, por fim, foi assinado o protocolo $n^{\circ} 24$, sobre coordenação de políticas macroeconômicas. 
câmbio por grandes setores e por segmentos através da expansão do comércio" (Ata para a Integração Brasileiro-Argentina, in BAUMANN \& LERDA, 1987, p. 154).

Em novembro de 1988, Brasil e Argentina assinaram o Tratado de Integração, Cooperação e Desenvolvimento, que dispôs sobre a criação de um espaço econômico comum em um prazo máximo de dez anos, removendo totalmente os impostos de importação e as restrições não tarifárias ao comércio de bens e serviços. Através de acordos específicos, deveria ocorrer também a harmonização de políticas aduaneiras, de comércio interno e externo, agrícola, industrial, de transportes e comunicações, científica e tecnológica, etc., e a coordenação de políticas monetária, fiscal, cambial e de capitais, sempre de maneira gradual. Essa seria a primeira etapa do processo. Depois, numa segunda etapa, buscar-se-ia chegar a um mercado comum. ${ }^{26}$

Depois da posse do novo presidente brasileiro, houve uma importante reunião em Buenos Aires, em julho de 1990. Collor de Mello e Menem decidiram, através da Ata de Buenos Aires, antecipar o estabelecimento do mercado comum bilateral em cinco anos, fixando a sua entrada em vigência em 31 de dezembro de 1994. Um primeiro anexo à ata especificou que a metodologia para a conformação do mercado comum teria, como coluna vertebral, as reduções generalizadas, lineares e automáticas dos impostos de importação até o nível zero no final de 1994. Os protocolos comerciais poderiam ser usados para acelerar o processo em setores específicos, e setores sensíveis poderiam ser objeto de acordos especiais.

Para muitos autores, o Programa de Integração e Cooperação entre Argentina e Brasil foi a experiência mais destacada de integração na América Latina nos anos 1980. ${ }^{27} \mathrm{O}$ comércio dos dois países com os mem-

26 Na mesma reunião houve também a assinatura, entre Argentina, Brasil e Uruguai, do Acordo Tripartite número 1, sobre Transporte Terrestre, e das Decisões Tripartites números 2 e 3 . Através desses documentos, encaminhava-se um processo de integração entre os três países, visando à incorporação do Uruguai aos acordos BrasilArgentina.

27 O resultado concreto da aplicação dos protocolos, no entanto, foi muito variável. Alguns tiveram bons resultados, como o Protocolo número 4, sobre expansão comercial, que se transformou no principal instrumento do processo de integração com a sua nova orientação. Outros tiveram resultado pequeno em relação às metas e enfrentaram muitas dificuldades na sua aplicação, como, por exemplo, o Protocolo número 2, sobre Trigo, e o número 1 , sobre Bens de Capital. Já um terceiro grupo de protocolos simplesmente não saiu do papel, sendo um exemplo, nos primeiros quatro anos, o sobre as Empresas Binacionais, que somente em 1990 teve uma ativação com a aprovação do Estatuto das Empresas Binacionais. Desse terceiro grupo também são exemplos os Protocolos número 6, sobre Assuntos Financeiros, número 7, sobre o Fundo 
bros da Aladi representava entre $70 \%$ e $80 \%$ do comércio total intra-Aladi (ARAÚJO JR., 1988, p. 43), o que demonstra a importância dos dois países no contexto econômico latino-americano e para o sucesso ou insucesso da Aadi como um todo. Vacchino (1987, p. 36) destaca que, "para muitos latinoamericanos, uma das causas principais dos escassos avanços e dos grandes períodos de estancamento do processo de integração latino-americano durante as três últimas décadas era a falta de entendimento entre Argentina e Brasil".

A integração entre Argentina e Brasil foi prejudicada pela permanência do problema da dívida externa, pois a necessidade de geração de saldos em moedas fortes continuou determinando a condução das políticas econômicas e as restrições às importações. Para se chegar a uma efetiva integração econômica é necessária uma política cambial coordenada. No entanto, dada a necessidade de geração de superávits comerciais para o pagamento do serviço da dívida externa, a coordenação cambial torna-se muito difícil. Depois de 1987, as mudanças de política cambial foram bruscas e contraditórias com os objetivos da integração entre Argentina e Brasil, tendo cada país seguido por caminhos sem qualquer coordenação entre ambos.

Outro problema foi que, segundo as palavras de Araújo Jr. (1991, p. 100), "o acordo firmado no Cone Sul não foi estimulado por pressões empresariais interessadas em aprofundar vínculos já estabelecidos, mas resultou de uma decisão governamental de reverter uma tendência histórica de deterioração nas relações econômicas dos dois países". Um aspecto a se destacar, também, é que, apesar de falar-se muito em integração econômica, a ênfase dos acordos Brasil-Argentina sempre foram muito mais no aspecto da cooperação econômica do que de integração propriamente dita.

Durante o ano de 1986, quando foi assinado o PICE, a conjuntura macroeconômica era a do sucesso dos planos Cruzado, no Brasil, e Austral, na Argentina. Entretanto, em 1987, quando os protocolos deveriam ter o início de sua aplicação, a conjuntura alterou-se completamente, com o fracasso dos dois planos econômicos. Dessa forma, desde o seu início a implantação do PICE foi obstruída por problemas econômicos e decisões polí-

de Investimentos, número 20, sobre a Moeda Comum, e o número 24, sobre Planejamento Econômico e Social, além de outros. Os impasses em alguns protocolos foram causados por indefinições de política setorial, apreensões com respeito à possibilidade de ocorrer dependência (na área energética), restrições orçamentárias, mudanças de prioridades, desinteresse de um ou ambos os países, ou outros motivos. 
ticas. O objetivo da integração foi mantido, mas as condições de operacionalização reduziram-se (HIRST, 1990).

O crescimento vertiginoso da inflação, a crise econômica e as dificuldades políticas de ambos os governos (Sarney e Alfonsín) levaram o processo de integração a um plano inferior entre as prioridades governamentais. Os problemas levaram a que a atenção das políticas econômicas ficasse centrada no curto prazo, em detrimento do médio e longo prazo. Esse quadro estendeu-se e, em 1989, coincidiu com conjunturas eleitorais nos dois países. Os novos governos eleitos, tanto na Argentina quanto no Brasil, adotaram diretrizes liberais, nas quais aparece uma consonância em relação à proposta de abertura da economia. Desse modo, o consenso neoliberal tornou-se a base política para as relações bilaterais seguintes (HIRST, 1990).

As declarações iniciais de ambos os governos propunham uma dinamização das relações com os países desenvolvidos, aparentemente secundarizando as relações intralatino-americanas e bilaterais. No entanto, logo os governos decidiram não impor um caráter excludente a essas relações e, dadas as atuais tendências internacionais de formação de blocos geoeconômicos, o tema da integração recuperou sua importância.

O crescimento dos países desenvolvidos na década de 1980 gerou um consenso de que a tendência de formação de espaços econômicos unificados é inevitável, e de que os países da América Latina devem seguir o mesmo caminho. O efeito demonstração provocado pelos demais projetos de integração em curso, mais o clima de harmonia e cooperação que substituiu "a antiga tradição de rivalidade e desconfiança" (ARAÚJO JR., 1991, p. 103), estimularam a manutenção dos objetivos de longo prazo do processo de integração.

Entretanto, o novo impulso integracionista sofreu importantes alterações de prioridades. O projeto de integração intra-setorial foi substituído pela proposta tradicional de integração intersetorial. O objetivo principal, deixando de lado a complementação industrial e a cooperação tecnológica, passou a ser a expansão comercial, promovida através de reduções de impostos de importação. Segundo Hirst (1990, p. 16), o caráter "dirigista" inicial (prioridade ao setor de bens de capital, por exemplo) foi substituído por uma gestão "que busca estimular os fluxos de comércio mais promissórios entre os dois países". Um dos indicadores da mudança de prioridade no processo de integração foi o abandono do instrumento dos protocolos, que proporcionava a abordagem de temas específicos. Também ocorreu a renúncia à coordenação de temas econômicos e políticos em nível internacional, com a volta das iniciativas individuais nesse campo. Essas tendências refle- 
tiram-se no passo seguinte do processo de integração, com a inclusão do Paraguai e Uruguai e a assinatura do Tratado do Mercosul.

\section{O MerCosul}

O Mercado Comum do Sul, entre Argentina, Brasil, Paraguai e Uruguai, foi criado em março de 1991, com a assinatura do Tratado de Assunção. O Mercosul foi resultante das mudanças de rumo do processo de integração entre Argentina e Brasil e da sua anterior ampliação parcial, com a inclusão do Uruguai.

A incorporação do Paraguai ao Programa de Integração e Cooperação Econômica (PICE), entre Argentina e Brasil, foi mais difícil por problemas políticos. ${ }^{28} \mathrm{O}$ Uruguai já possuía importantes acordos bilaterais com a Argentina e o Brasil desde os anos 1970, o que estimulou e facilitou sua incorporação ao PICE. ${ }^{29}$

A partir disso, ocorreu em Brasília, em agosto de 1990, uma reunião de Ministros de Relações Exteriores e de Economia da Argentina, Brasil, Chile e Uruguai. Nesse momento, admitiu-se o ingresso do Uruguai no projeto do mercado comum dos dois primeiros países, e o Chile e o Paraguai

28 A marginalização do Paraguai foi proposta pelo governo Alfonsín, que defendia o retorno da democracia àquele país (HIRST, 1990a). A troca de governo no Paraguai, em fevereiro de 1989, superou esse obstáculo, e vários acordos foram assinados com a Argentina a partir desse momento. Com o Brasil, o relacionamento bilateral não sofreu maiores alterações. Desse modo, o espaço foi aberto, com o Brasil e a Argentina defendendo a incorporação do Paraguai ao processo de integração, e esse país também demonstrando interesse em participar. Para o Paraguai, os interesses econômicos são grandes, pois o Brasil é o seu principal sócio comercial, ficando a Argentina em terceiro lugar.

29 Em agosto de 1974 foi firmado o Convênio Argentino-Uruguaio de Cooperação Econômica (Cauce), que sofreu ampliações e modificações em 1976, 1982 e 1985. Com o Brasil foi firmado, em junho de 1975, o Protocolo de Expansão Comercial (PEC), que também foi alterado e ampliado posteriormente (em 1982, 1985 e 1986). Dada a importância do comércio com Brasil e Argentina para o Uruguai, este país ficou com receio de perder suas vantagens, proporcionadas pelo Cauce e PEC, com a liberação comercial entre os dois primeiros países. Os uruguaios ficaram preocupados com a aceleração do processo integracionista, que ameaçava deixá-los num relativo isolamento econômico. Isso, principalmente, provocou o interesse do Uruguai em participar dos acordos entre Brasil e Argentina. 
foram convidados a se incorporar. O Paraguai aceitou esse convite imediatamente, enquanto o Chile decidiu "observar o processo" (BONILLA, 1991) ${ }^{30}$

O Tratado de Assunção foi assinado em 26 de março de 1991, quando se reuniram na capital paraguaia os presidentes da Argentina, Brasil, Paraguai e Uruguai. ${ }^{31}$ Nesse acordo, que reproduz muitos pontos já negociados e assinados entre o Brasil e a Argentina, os quatro países decidiram constituir o Mercado Comum do Sul (Mercosul) a partir de 31 de dezembro de $1994 .{ }^{32}$

Haveria um período de transição, até 31 de dezembro de 1994, durante o qual os países membros comprometiam-se a coordenar gradualmente suas políticas macroeconômicas, a implantar uma tarifa externa comum e a adotar acordos setoriais visando facilitar a utilização e mobilidade dos fatores de produção e alcançar escalas de produção eficientes.

Além disto, haveria um Programa de Liberação Comercial (Anexo I do tratado), com reduções tarifárias progressivas, lineares e automáticas, com o objetivo de chegar-se ao final de 1994 com tarifas zeradas sobre a totalidade do universo tarifário e com a eliminação de outras restrições comerciais. ${ }^{33}$ No período de transição haveria também a adoção de um Regime

30 A posição do Chile frente ao projeto de integração é específica. Esse país, dado o projeto liberalizante, tanto do governo militar quanto do governo civil posterior a março de 1990, possui uma economia com nível de abertura elevado, o que o leva a desinteressar-se por um projeto que visa basicamente reduzir impostos de importação. A sua posição foi de crítica às políticas econômicas da Argentina e do Brasil, consideradas por ele protecionistas, e à situação de instabilidade macroeconômica desses países. Dessa forma, o Chile preferiu negociar bilateralmente sobre temas específicos.

31 Após a aprovação do Tratado de Assunção pelos respectivos parlamentos, os instrumentos de ratificação do Brasil e da Argentina foram entregues ao governo paraguaio (conforme determinação do tratado) no dia 30 de outubro de 1991. Essa formalidade já havia sido cumprida pelo Paraguai e Uruguai anteriormente. Desse modo, o tratado entrou em vigor, de acordo com suas normas, 30 dias após aquela data, ou seja, em 29 de novembro de 1991.

32 O Mercosul implicaria em livre circulação de bens, serviços e fatores produtivos; eliminação de direitos alfandegários e restrições não tarifárias; estabelecimento de uma tarifa externa comum e de uma política comercial comum em relação a terceiros países ou grupos de países; coordenação de posições em foros econômico-comerciais externos; coordenação de políticas macroeconômicas e setoriais visando assegurar condições adequadas de concorrência entre os quatro países; e compromisso de harmonização de legislações pertinentes.

33 O cronograma de eliminação de tarifas foi o seguinte: $47 \%$ em 30 de junho de 1991, elevando-se 7\% por semestre até 30 de junho de 1994 (quando chegaria a $89 \%$ ), e $100 \%$ em 31 de dezembro de 1994 . Esse percentual deveria incidir sempre sobre a tarifa vigente no momento da sua aplicação, sendo essa tarifa a mais favorável 
Geral de Origem (Anexo II), um Sistema de Solução de Controvérsias (Anexo III) e Cláusulas de Salvaguarda (Anexo IV). ${ }^{34}$ A administração e execução do Tratado de Assunção ficariam a cargo do Conselho do Mercado Comum e do Grupo Mercado Comum. ${ }^{35}$ Determinou-se também que, antes de 31 de dezembro de 1994, haveria uma reunião para chegar-se à estrutura institucional definitiva do Mercosul. O Tratado definiu também o estabelecimento de uma Comissão Parlamentar Conjunta do Mercosul, com o objetivo de facilitar a implantação do mesmo. Por fim, o Anexo V criou dez subgrupos ligados ao Grupo Mercado Comum, que teriam como função auxiliar as atividades desse último. ${ }^{36}$

aplicada às importações procedentes de fora da ALADI. Ficariam excluídos desse cronograma os produtos das Listas de Exceções, sendo estes em número de 394 para a Argentina, 324 para o Brasil, 439 para o Paraguai e 960 para o Uruguai. Esses produtos teriam suas tarifas também eliminadas até o final de 1994, mas com outro cronograma. Para Argentina e Brasil a Lista de Exceção teria o seu número de produtos reduzido em $20 \%$ ao ano, enquanto para Paraguai e Uruguai a redução ocorreria em 10\% do número de produtos na data de entrada em vigor do Tratado de Assunção, 10\% em 31 de dezembro de 1991, e 20\% ao ano até sua eliminação total em 31 de dezembro de 1995. Ou seja, estes últimos dois países teriam um ano a mais para eliminar suas Listas de Exceções.

34 O Regime de Origem fixa normas e critérios para a determinação da origem das mercadorias transacionadas no âmbito do Mercosul, disciplinando o comércio no sentido de evitar que produtos importados de fora dos quatro países sejam reexportados com os benefícios do Mercosul. O Anexo III determina que as controvérsias sejam solucionadas através de negociações diretas ou, não sendo isto possível, via o Grupo Mercado Comum ou via o Conselho do Mercado Comum, enquanto não se chegar ao Sistema Permanente de Solução de Controvérsias do Mercado Comum. O Anexo IV determina que, em casos excepcionais, um país poderá solicitar a adoção de salvaguardas transitórias à importação de determinado produto.

35 O Conselho é o órgão superior, cabendo-lhe a condução política e as principais decisões, sendo integrado pelos Ministros de Relações Exteriores e de Economia dos países membros. O Conselho deveria reunir-se pelo menos uma vez por ano com a participação dos Presidentes dos quatro países. O Grupo Mercado Comum é o órgão executivo, sendo coordenado pelos Ministros das Relações Exteriores, e tendo a participação dos Ministérios da Economia e dos Bancos Centrais. O Grupo Mercado Comum contaria com uma Secretaria Administrativa, com sede em Montevidéu.

36 Estes subgrupos são os seguintes: Assuntos Comerciais, Assuntos Aduaneiros, Normas Técnicas, Política Fiscal e Monetária Relacionadas com o Comércio, Transporte Terrestre, Transporte Marítimo, Política Industrial e Tecnológica, Política Agrícola, Política Energética e Coordenação de Políticas Macroeconômicas. Posteriormente, foi aprovada a criação do subgrupo de trabalho sobre Assuntos Trabalhistas e Sociais. Esse subgrupo técnico seria coordenado pelos respectivos Ministérios do Trabalho, e dele participariam também trabalhadores e empresários, analisando as conseqüências do Mercosul no mercado de trabalho e outros aspectos sociais. 
O Tratado de Assunção possuía muitas metas genéricas e ambiciosas. Apesar dessas metas pretensiosas, as medidas concretas tomadas foram basicamente de caráter comercial, consolidando as últimas tendências dos acordos entre Brasil e Argentina, e também em concordância com as prioridades das políticas internas de cada país. O Tratado foi gerado basicamente a partir dos poderes executivos, sem participação, na sua formulação, da sociedade ou dos empresários. Um acordo que não resultou de pressões econômicas, mas sim de definições políticas e de percepções econômicas dos governos.

Inicialmente, existiram dificuldades derivadas dos problemas macroeconômicos dos países envolvidos. A alta inflação, principalmente no Brasil, inicialmente, impediu uma maior coordenação de políticas cambiais. O programa econômico argentino, com uma taxa de câmbio fixa, também tornou difícil a coordenação de políticas com outros países. Quando a inflação é muito alta as flutuações cambiais tendem a ser violentas, tornando o imposto de importação menos relevante para a determinação do comércio, e colocando condições de extrema imprevisibilidade para os empresários.

A definição sobre uma tarifa externa comum também foi difícil pelas diferenças existentes entre as políticas e prioridades dos países. A existência de subsídios internos é outro fator que tem influência no processo e que precisa de definições. Desse modo, a coordenação de políticas macroeconômicas, colocada como meta, ainda é algo que está longe da realidade. Existia uma grande desconfiança com a capacidade dos governos de abrirem mão da liberdade de formulação de política econômica.

Havia também restrições ao processo por temor da concorrência ou pelas conseqüências negativas que ele poderia trazer. Dessa forma, existiam resistências em setores industriais, agropecuários, nos meios sindicais, políticos, etc. Esse comportamento é, muitas vezes, causado pela falta de canais de participação e de uma maior discussão na sociedade. No entanto, também é conseqüência da falta de mecanismos compensatórios contra possíveis danos.

\section{DESEMPENHO ECONÔMICO}

Essa seção apresenta sumariamente, para os membros do Mercosul, dados sobre o desempenho econômico e resultados comerciais da integração, comparativamente aos anos 1980.

A evolução do PIB, após a entrada em vigor do Mercosul, foi mais favorável que no período anterior (menos para o Paraguai), conforme a tabela 1. 
Argentina e Uruguai passaram por virtuais estagnações econômicas nos anos 1980, e aceleraram fortemente seu crescimento após 1990. O Brasil apresentou uma variação de resultados menor. Essa fase ascendente durou oito anos, até 1998 (ver gráfico 1). Após 1998, os quatro países apresentaram resultados piores, com destaque para Argentina e Uruguai, que possuem desempenhos muito semelhantes. Em quatro anos (1999 a 2002), o PIB argentino caiu $18,4 \%$ e o uruguaio, $17,6 \%$, enquanto o Paraguai ficou estagnado e o Brasil, apesar do fraco desempenho, ainda foi o melhor. A partir de 2003 ocorreu substancial recuperação para a Argentina e, depois desse ano, igualmente para o Brasil e o Uruguai.

Tabela 1 - TAXAS MÉDIAS ANUAIS DE CRESCIMENTO REAL DO PIB - 1980-2005

\begin{tabular}{ccccc}
\hline Períodos & Argentina & Brasil & Paraguai & Uruguai \\
\hline $1980-90$ & $-0,9$ & 2,2 & 3,8 & 1,0 \\
$1991-98$ & 5,7 & 2,7 & 2,5 & 4,4 \\
$1999-02$ & $-4,9$ & 2,1 & 0,1 & $-4,7$ \\
$2003-05$ & 7,9 & 2,7 & 2,4 & 6,4 \\
\hline
\end{tabular}

Dados de 2004 são preliminares e de 2005 são estimativas.

FONTES: IMF (2005) e Cepal (2005)

Gráfico 1 - EVOLUÇÃO DO PIB - 1980-2005 (ÍNDICE DE 1991 = 100,0)

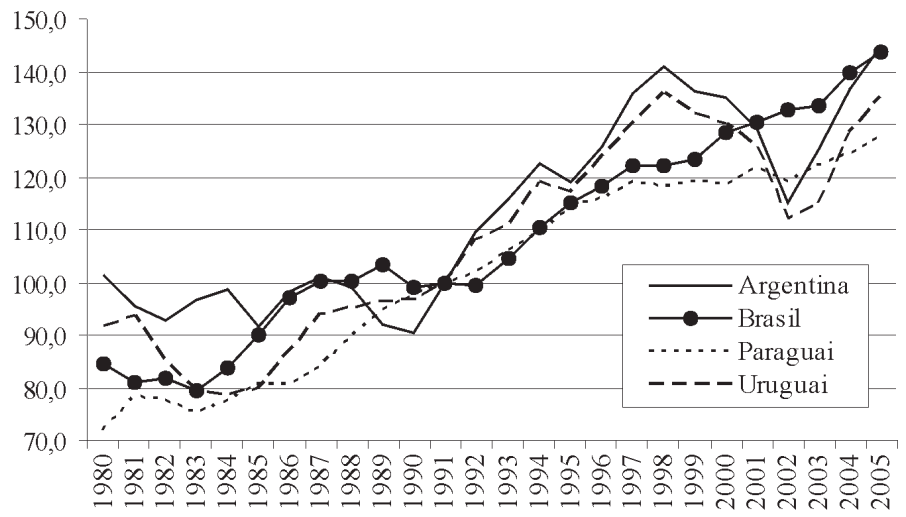

FONTE: IMF (2005) e Cepal (2005)

(2004: preliminar; 2005: estimativa) 
Desde meados dos anos 1980, o coeficiente de integração ${ }^{37}$ vinha crescendo para os países do Mercosul (menos o Paraguai), como se pode observar no gráfico 2 . No entanto, o crescimento desse coeficiente se acelerou logo após 1991 para os quatro países, revertendo-se a tendência anterior de diminuição no caso do Paraguai. Dessa forma, para a Argentina, a participação da corrente de comércio no Mercosul subiu de pouco mais de $10 \%$ para 30\% entre os anos 1980 e 1990, enquanto para o Brasil a participação evoluiu de menos de 5\% para mais de 15\%. Para o Uruguai, a evolução foi de pouco mais de $20 \%$ para quase $50 \%$, e para o Paraguai, foi de cerca de $45 \%$ para $55 \%$. Esse desempenho positivo deve ter influenciado positivamente as taxas de crescimento do PIB dos quatro países entre os anos de 1991 e 1998. Por outro lado, o próprio crescimento, com origem em outros fatores, pode ter estimulado o comércio intrazonal, que nesse período tornou-se muito aberto. No final dos anos 1990 e início dos 2000, no entanto, o coeficiente de integração reduziu-se fortemente para Argentina, Brasil e Uruguai, repetindo as experiências anteriores de crises econômicas afetando negativamente a integração. Nos anos de 2003 e 2004 essa relação parou de se reduzir para o Brasil e a Argentina, mas ainda não se recuperou substancialmente.

Em valores absolutos, a redução do comércio entre 1998 e 2002 aparece como ainda mais surpreendente. Para a Argentina a corrente comercial (exportações mais importações) para o Mercosul diminuiu 50,4\%, com as importações sendo cortadas em 63,5\% (enquanto as importações totais reduziram-se em 71,4\%). No Brasil, o fluxo comercial com o Mercosul foi reduzido, nesse período, em 50,8\%, com queda de $62,7 \%$ nas exportações. Para o Uruguai o desempenho é semelhante, com redução da corrente comercial de $51,3 \%$ e das exportações em $60,4 \%$. Percebe-se que no Brasil e no Uruguai aparece a contraface do desempenho argentino. O Paraguai, nesses mesmos anos, também apresentou fluxo comercial decrescente no Mercosul $(25,6 \%)$ e em termos totais $(31,2 \%)$, resultantes de cortes nas importações. importações totais.

37 Exportações mais importações no MERCOSUL sobre exportações mais 
Gráfico 2 - COEFICIENTES DE INTEGRAÇÃO - 1980-2004 (EXPORTAÇÕES + IMPORTAÇÕES NO MERCOSUL / EXPORTAÇÕES +IMPORTAÇÕES TOTAIS)

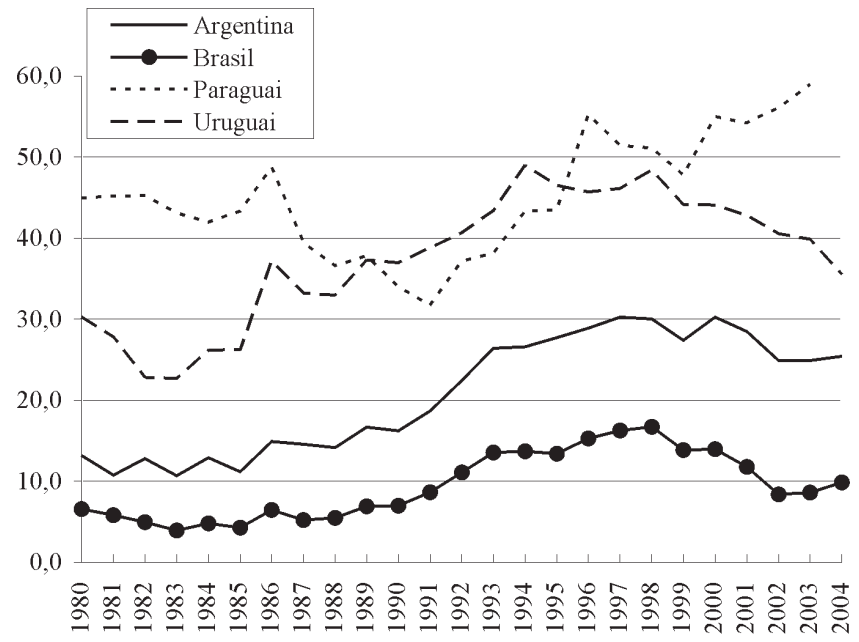

Dados de 2004 para Argentina: 7 meses; Uruguai: 9 mese

FONTES: CEPAL (2005) e ALADI (2005)

A participação das exportações totais dos quatro países no MERCOSUL elevou-se de pouco mais de $0,1 \%$ das exportações mundiais, nos anos 1980, para quase $0,4 \%$, no final dos anos 1990 . No entanto, a participação das exportações dos quatro países para o resto do mundo apresentou resultado oposto, conforme se percebe no gráfico 3. Entre 1991 e 1998, houve aercosul, quanto para o mundo (incluindo o Mercosul), apesar de não recuperar os níveis alcançados em meados dos anos 1980. Portanto, houve um processo de criação de comércio, apesar de restrito. Depois de 1998, ocorreu, primeiramente, uma redução geral da participação das exportações, tanto para o Mercosul, quanto para o resto do mundo e, após, uma continuidade da queda no Mercosul, mas um aumento para o resto do mundo. Isso mostra que o comércio intrazonal é relativamente mais beneficiado quando as economias estão crescendo, mas é sacrificado quando essas estão em crise. Em termos gerais, aparentemente ocorreu um processo de desvio de comércio, para o Mercosul no crescimento e para fora do Mercosul nas crises, com uma pequena criação de comércio. 


\section{Gráfico 3 - PARTICIPAÇÃO PERCENTUAL DAS EXPORTAÇÕES DOS PAÍ- SES DO MERCOSUL NAS EXPORTAÇÕES MUNDIAIS - 1980- 2003}

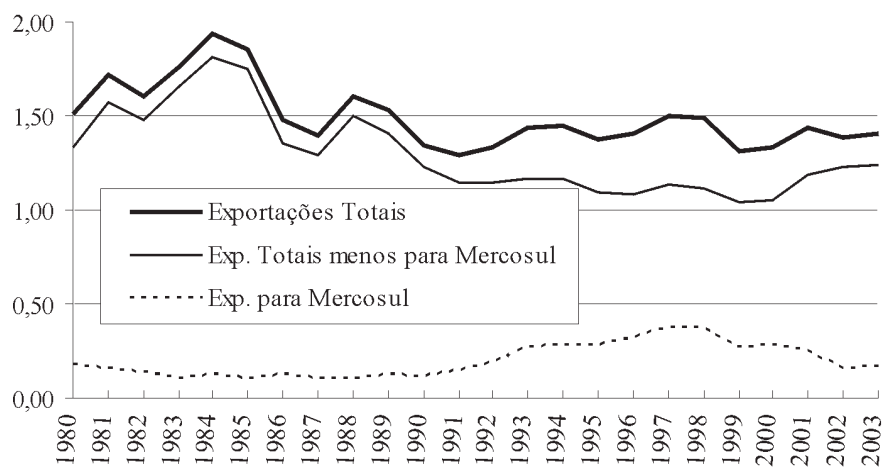

FONTES: Cepal(2005), Aladi (2005) e Ipeadata (2005)

\section{CONCLUSÕES}

Nas últimas quatro décadas, ocorreram várias tentativas de integração econômica na América Latina. Os resultados, em geral, não foram muito alentadores, tendo os fracassos superado os sucessos.

Os modelos de integração que se adotaram não foram adequados, por exemplo, para impulsionar o desenvolvimento dos países mais pobres da região. A abolição ou redução de barreiras comerciais, isoladamente, não resulta em um processo eqüitativo entre os países, por mais que os prazos sejam dilatados ou que haja exceções para os países mais débeis. Pelo fato de os projetos de integração não terem assumido, em geral, um papel de prioridade nos programas econômicos dos governos, não chegaram também a ter influência decisiva no desenvolvimento da região.

A integração, por outro lado, nunca cumpriu o papel anticíclico que dela se esperava. Ao contrário, quando os países latino-americanos entram em crise, os processos de integração normalmente também retrocedem, com o comércio intra-regional sofrendo grandes quedas. No caso do Mercosul, no período de crise recente (1999 a 2002), isso se repetiu. No entanto, existe uma expectativa de melhora do desempenho para os próximos anos, com a retomada do crescimento econômico e dos fluxos comerciais 
intrazonais, o que já pode ser percebido pelos dados de 2003 (ver gráficos 2 e 3), apesar de que de forma ainda fraca.

O que se verificou, tipicamente, foi uma grande dose de voluntarismo nos acordos, sem o necessário apoio da sociedade e dos empresários, criando-se, também, uma demasiada expectativa com o processo. A integração econômica oferece algumas vantagens, mas isoladamente não é eficaz para superar os problemas econômicos e sociais dos países, sem ser acompanhada de outras transformações econômicas, políticas e sociais.

Existe, também, uma grande contradição entre o que está escrito nos acordos e o que realmente os governos estão dispostos a fazer. O que é assinado, em geral e em grande parte, fica como meta para o futuro, dependendo de novas iniciativas e de ratificações, e, depois, do seu efetivo cumprimento.

A crise dos anos 1980 levou os países latino-americanos a buscarem alternativas de desenvolvimento, dada a crescente marginalização do subcontinente. Dessa forma, de acordo com as tendências mundiais, criou-se um generalizado consenso liberal entre as elites da América Latina, gerando um novo enfoque para a integração, que pode ser chamado de estratégia de integração com inserção internacional. Rompe-se, portanto, com a visão anterior de integração como meio para alcançar a industrialização via ampliação de mercados. Mesmo os setores conservadores dos países ricos passam a ver a formação de blocos regionais no Terceiro Mundo com mais aceitação. Antes, percebiam essas iniciativas como protecionistas. Agora, porém, com o novo enfoque liberal, entendem que os blocos podem vir a diminuir as barreiras ao comércio internacional. Segundo esses setores, os países do Terceiro Mundo compreenderam que o seu sucesso depende de sua capacidade de competição externa e, para isso, reduzindo as barreiras entre si, tornar-se-iam mais preparados para alcançar o mercado mundial.

Ao contrário, no entanto, do previsto na idéia de que a integração regional seria um second best que geraria mais eficiência e que, por conseqüência, sendo bem sucedida levaria ao first best da liberalização tarifária multilateral, na América Latina essa última precedeu ou ocorreu concomitantemente às experiências mais recentes de integração (GONÇALVES et al., 1998, p. 83 e 86).

A retomada do processo integracionista na América Latina deu-se no momento em que isso também aconteceu no Primeiro Mundo e em outras regiões do Terceiro Mundo. Essa tendência é fruto das profundas alterações do sistema capitalista mundial ocorridas nas últimas décadas. Desse modo, assiste-se a uma crescente internacionalização do capital, da produção, dos fluxos financeiros e do processo de trabalho. Essa transnacionalização eco- 
nômica gerou uma crescente dificuldade para a condução das políticas econômicas nacionais de forma autônoma.

A mundialização da economia capitalista contrasta com a tendência à regionalização através da formação dos blocos geoeconômicos. Essa pode ser entendida como a forma concreta, nesse momento, que viabiliza parcialmente a regulação econômica supranacional, institucionalizando o movimento concreto do capital. Ou seja, a integração, no Primeiro Mundo, significa uma tentativa de retomada da regulação estatal sobre o processo econômico supranacionalizado, com o intuito de facilitar a acumulação de capital. Esse movimento cria, por outro lado, novas formas de concorrência e de conflitos, entre blocos e países ou entre os blocos.

Este novo contexto internacional, que estaria levando a América Latina a um maior isolamento econômico, provoca a busca de alternativas entre os países do subcontinente. Entre essas alternativas, incluem-se os processos de integração.

As vantagens de uma integração na América Latina seriam muito grandes, e poderiam ultrapassar os aspectos comerciais. As mudanças tecnológicas atuais afetam as vantagens comparativas tradicionais dos países pobres (mão-de-obra e matérias-primas), o que necessita de uma resposta que pode ser potencializada se houver um desenvolvimento coletivo. Os investimentos públicos conjuntos, principalmente em infra-estrutura, são outro campo de ação, como também o fortalecimento de posições em negociações com terceiros países ou blocos de países.

Um fator fundamental para determinar a possibilidade de sucesso de um projeto de integração é a participação econômica ativa dos empresários dos países envolvidos. Nesse sentido, podemos detectar que o relacionamento empresarial no Mercosul tem ido além de simples operações de exportações e importações. Ocorreram vários encontros por setores entre empresários dos quatro países, o que também estimulou a integração. Dessa forma, houve resistências, mas não rejeição. Além disso, surgiram casos de associações, joint-ventures e aquisições ou participações acionárias, visando o aproveitamento do mercado ampliado que o Mercosul traria e também de outros interesses comerciais, como conseqüência não só do Mercosul, mas principalmente dos acordos entre Brasil e Argentina.

A tendência atual, no entanto, é de ênfase nos aspectos de liberação comercial, e com uma participação estatal subsidiária. Isso tende a beneficiar o capital já internacionalizado, mas que não depende da integração formal. Nas experiências anteriores, o capital privado muitas vezes sentiu-se ameaçado com a integração, tendo, por isso, uma posição predominante de 
descaso. Na experiência atual, tem-se que reavaliar a correlação de forças entre o capital que se sente prejudicado e o que se sente beneficiado. Um fator novo é uma relativa internacionalização do capital nacional dos países do Mercosul, com investimentos no exterior. A experiência adquirida com a grande ampliação das exportações na década de 1980 levou a associações, acordos, criação de empresas, abertura de filiais, etc., entre os quatro países. Esse fato, ainda incipiente, mas crescente, acontece à margem dos acordos formais, podendo, no entanto, ter uma influência decisiva sobre esses. Talvez agora, efetivamente, o capital, pelos seus interesses econômicos, apoiará um processo de integração latino-americano. Se houver, além disso, um relativo consenso social sobre as vantagens da integração, um rumo diferente das tentativas de integração anteriores na região pode ser determinado ao Mercosul.

\section{RESUMO}

$\mathrm{O}$ artigo analisa as principais experiências de integração econômica na América Latina, com destaque para os processos que deram origem ao Mercosul. Inicialmente, são discutidos os antecedentes históricos e as propostas da Cepal, e o desenvolvimento e desempenho da Alalc e da Aladi. Sobre o processo de integração bilateral entre Brasil e Argentina, nos anos 1980, destaca-se a realização de acordos intrasetoriais como uma maneira inovadora de integração. O Mercosul é tratado no contexto de sua constituição e primeiros resultados, enquanto um processo político bem sucedido, voltando-se, entretanto, a um padrão mais liberal de integração. Seu desempenho econômico até o presente é analisado a seguir, com destaque para a evolução e as dificuldades macroeconômicas, em suas relações com a integração. Apresentam-se também indicadores, com resultados positivos e negativos, de desempenho do Mercosul. Na conclusão, são discutidas a evolução e as perspectivas da integração econômica latino-americana, em um contexto de globalização e ameaça de marginalização e de baixo desempenho econômico regional, destacando-se a importância da participação empresarial e social na determinação do rumo das novas experiências.

Palavras-chave: Integração econômica na América Latina, Mercosul. 


\begin{abstract}
The article analyzes the main experiences of economic integration in Latin America, with prominence for the processes that created Mercosul. Initially, are discussed the historical antecedents and the proposals of Cepal, and the development and performance of Alalc and Aladi. About the process of bilateral integration between Brazil and Argentina, in the 1980's years, is standing out the realization of intra-sectorial agreements as an innovative way of integration. The Mercosul is treated in the context of its constitution and first results, as a well happened political process, returning, however, to a more liberal integration pattern. Its economic performance until present is analyzed after, with prominence for the evolution and the macroeconomics difficulties, in their relationships with the integration. The paper also presents indicators, with positive and negative results, of Mercosul's performance. In the conclusion, the evolution and the perspectives of the latin-american economic integration are discussed, in a context of globalization and marginalization threat and of low regional economic performance, standing out the importance of the business community's and social participation to determine the direction of the new experiences.

Key-words: Economic integration in Latin America, Mercosul.
\end{abstract}

\title{
REFERÊNCIAS
}

ALADI. Disponível em: <www.aladi.org>. Acesso em: jun. 2005.

ARAÚJO JR., J. T.. Os fundamentos econômicos do programa de integração ArgentinaBrasil. Revista de Economia Política, São Paulo, v. 8, n. 3 (31), jul./set. 1988.

Integração econômica e harmonização de políticas na América do Norte e no Cone Sul. Revista de Economia Política, São Paulo, v. 11, n. 2 (42), abr./jun. 1991.

BANDEIRA, M. O eixo Argentina-Brasil: o processo de integração da América Latina. Brasília: Universidade de Brasília, 1987.

BAUMANN, R.; CANUTO, O.; GONÇALVES, R. Economia internacional: teoria e experiência brasileira. Rio de Janeiro: Elsevier/Campus, 2004.

BAUMANN, R.; LERDA, J. C. A integração econômica entre Brasil, Argentina e Uruguai: que tipo de integração se pretende? In: BAUMANN, R.; LERDA, J. C. (Orgs.). BrasilArgentina-Uruguai: a integração em debate. São Paulo; Brasília: Marco Zero; Universidade de Brasília, 1987. 
BID. Progresso sócio-econômico na América Latina: integração econômica. Washington: BID, 1984. Relatório.

BLEJER, M. I. Panorama analítico da integração econômica. In: BID. Progresso sócioeconômico na América Latino: integração econômica. Washington: BID, 1984. Relatório. BONILLA, S. A. Mercosur e integración. Montevideo: Fundación de Cultura Universitaria, 1991.

BOUZAS, R.; FANELLI, J. M. Mercosur: integración y crecimiento. Buenos Aires: Altamira, 2002.

CAMPBELL, J. (Org.). Mercosul: entre a realidade e a utopia. Rio de Janeiro: Relume Dumará, 2000.

CEPAL. O mercado comum latino-americano. In: BIELSCHOWSKY, R. (Org.). Cinqüenta anos de pensamento na Cepal. Rio de Janeiro: Record, 2000a.

O regionalismo aberto na América Latina e no Caribe: a integração econômica a serviço da transformação produtiva com eqüidade. In: BIELSCHOWSKY, R. (Org.). Cinqüenta anos de pensamento na Cepal. Rio de Janeiro: Record, 2000b.

Disponível em: <www.cepal.org>. Acesso em: jun. 2005.

FFRENCH-DAVIS, R. Integración económica. Integración Latinoamericana, Buenos Aires: Intal, n. 142, jan./fev. 1989.

GERARDI, R. E. La repercusión de la crisis en los esquemas de integración. Integración Latinoamericana, Buenos Aires: Intal, n. 116, set.1986.

GONÇALVES, R. et al. A nova economia internacional: uma perspectiva brasileira. Rio de Janeiro: Campus, 1998.

HIRST, M. Contexto e estratégia do programa de integração Argentina-Brasil. Revista de Economia Política, São Paulo, v. 8, n. 3, ano 31, jul./set. 1988.

El Programa de Integración Argentina-Brasil: concepción original y ajustes recientes. Buenos Aires: Intal; Fundación Banco de Boston, 1990.

IMF. World Economic Outlook. Disponível em: <www.imf.org>. Acesso em: jun. 2005.

INTAL. Texto del Tratado de ALADI (Tratado de Montevideo 1980). Integración Latinoamericana, Buenos Aires: Intal, n. 47, jun. 1980.

IPEADATA. Disponível em: <www.ipeadata.gov.br>. Acesso em: jun. 2005.

LERDA, J. C.; MUSSI, C. Coordenação de políticas macroeconômicas no contexto da integração argentino-brasileira: uma avaliação crítica. In: BAUMANN, R.; LERDA, J. C. (Orgs.). Brasil-Argentina-Uruguai: a integração em debate. São Paulo; Brasília: Marco Zero; Universidade de Brasília, 1987.

MAGARIÑOS, G. Primer decenio de la ALADI. Principios e instituciones. Integración Latinoamericana, Buenos Aires: Intal, n. 160, set. 1990.

Evolución de la integración en el marco de la ALADI. Integración Latinoamericana, Buenos Aires: Intal, n. 165, mar. 1991.

MARTÍNEZ, O. et al. El proceso de integración. La Habana: Editorial de Ciencias Sociales, 1978.

MENEZES, A. da M. Do sonho à realidade: a integração econômica latino-americana. 
São Paulo: Alfa-Ômega, 1990.

MERCOSUL. Disponível em: <www.mercosur.org.uy>. Acesso em: set. 2004.

MUNHOZ, D. G. Dívida externa - um viés antiintegração. In: BAUMANN, R.; LERDA, J. C. (Orgs.). Brasil-Argentina-Uruguai: a integração em debate. São Paulo; Brasília: Marco Zero; Universidade de Brasília, 1987.

ORDÓÑEZ, J. L. Décimo aniversario de la ALADI. Integración Latinoamericana, Buenos Aires: Intal, n. 160, set. 1990.

PAIVA, P.; GAZEL, R. Mercosur: past, present, and future. Nova Economia, Belo Horizonte, v. 13, n. 2, jul./dez. 2003.

RATTNER, H. Mercosul e Alca: o futuro incerto dos países sul-americanos. São Paulo: Edusp, 2002.

SARTI, F. Crise e perspectivas do Mercosul. In: LAPLANE, M; COUTINHO, L.; HIRATUKA, C. (Orgs.). Internacionalização e desenvolvimento da indústria no Brasil. São Paulo: Unesp; Campinas: IE/Unicamp, 2003.

SILVA, C. J. da. Antecedentes históricos do processo de integração latino-americana: ALALC, MCCA, Pacto Andino. In: SEITENFUS, V. M.; DE BONI, L. A. (Coords.). Temas de integração latino-americana. Petrópolis; Porto Alegre: Vozes; UFRGS, 1990. VACCHINO, J. M. Momentos claves en la história de Alalc-Aladi. Integración Latinoamericana, Buenos Aires: Intal, n. 126, ago. 1987.

VELloso, J. P. dos R. (Org.). O Brasil e o Plano Bush: oportunidades e riscos numa futura integração das Américas. São Paulo: Nobel, 1991.

VERSIANI, F. R. A experiência latino-americana de integração e os novos acordos Brasil-Argentina-Uruguai. In: BAUMANN, R.; LERDA, J. C. (Orgs.). Brasil-ArgentinaUruguai: a integração em debate. São Paulo; Brasília: Marco Zero; Universidade de Brasília, 1987.

(Org.). Integración de la América Latina: experiencias y perspectivas. México: Fondo de Cultura Económica, 1967.

WIONCZEK, Miguel S. La historia del Tratado de Montevideo. In: SALGADO P., G. (Compilador). Economia de la integración Latinoamericana: lecturas seleccionadas. Buenos Aires: BID-Intal, 1989. 